\title{
Pseudomonas pseudoflava, a New Species of Hydrogen- Oxidizing Bacteria: Its Differentiation from Pseudomonas flava and Other Yellow-Pigmented, Gram-Negative, Hydrogen-Oxidizing Species
}

\author{
G. AULING, ${ }^{1}$ M. REH, ${ }^{2}$ C. M. LEE, ${ }^{2}$ AND H. G. SCHLEGEL ${ }^{1,2}$ \\ Institut für Mikrobiologie der Universität Göttingen ${ }^{2}$ und Institut für Mikrobiologie der Gesellschaft für \\ Strahlen und Umweltforschung $m b{ }^{1}$ Munich, in Göttingen, Federal Republic of Germany
}

Five new strains of yellow-pigmented, gram-negative, motile, hydrogen-oxidizing bacteria were isolated; each served as a host for simultaneously isolated bacteriophages. These isolates and two additional strains were compared with other gram-negative, hydrogen-oxidizing bacteria with respect to morphology; nutritional and biochemical properties; growth parameters; cytochrome content; pigment production; susceptibility to bacteriophages, bacteriostatic agents, and antibiotics; deoxyribonucleic acid base composition; and deoxyribonucleic aciddeoxyribonucleic acid homology. Six of the strains were characterized by a high degree of interstrain similarity and were found to be related to Pseudomonas flava. However, due to basic differences between these strains and $P$. flava, the former are regarded as comprising a new species for which, because of its moderate relationship to $P$. flava, the name Pseudomonas pseudoflava is proposed. The type strain of $P$. pseudoflava, GA3, has been deposited with the Deutsche Sammlung von Mikroorganismen in Göttingen under the number DSM 1034.

The facultatively autotrophic hydrogen-oxidizing bacteria-commonly called hydrogen bacteria-are a taxonomically heterogeneous group among the chemolithoautotrophs. Their physiology has recently been reviewed by Schlegel (30). In the summer and autumn of 1973 , about 80 strains of hydrogen bacteria were isolated and tested for ability to serve as hosts for simultaneously isolated bacteriophages. Among these, only a few strains of polarly flagellated bacteria forming yellow colonies were found to be susceptible to the bacteriophages. These host bacteria had a high interstrain similarity and were considered to be related to Pseudomonas flava (15).

Further studies were aimed at characterizing the six host bacteria, evaluating their similarity and delineating them from other yellow-pigmented hydrogen bacteria, and determining their taxonomic niche. For direct comparison with these strains, several type strains and some other strains of hydrogen bacteria, especially the yellow-pigmented ones, were included in this study. Morphological features; nutritional and biochemical properties; growth parameters; the cytochromes; pigmentation; and susceptibility to bacteriophages, bacteriostatic agents, and antibiotics were investigated. In addition, the serological relationships to other gram-negative hydrogen bacteria and the deoxyribonucleic acid
(DNA) base compositions and DNA-DNA homologies of these strains were studied.

As a result of these studies, it was concluded that the six new isolates belong to a new species, for which we propose the name Pseudomonas pseudoflava (pseu.do.fláva. Gr. adj. pseudes false; L. fem. adj. flava yellow; M.L. fem. adj. pseudoflava not the true [Pseudomonas] flava [so named because of its moderately close relationship to $P$. flava]).

\section{MATERIALS AND METHODS}

Bacterial strains. The strains used in this study are listed in Table 1. The new strains of hydrogenoxidizing bacteria were isolated by an enrichment procedure designed for the simultaneous isolation of bacteriophages and hydrogen-utilizing host bacteria. The procedure has been described elsewhere (la).

Growth media and maintenance of strains. For growth of the hydrogen bacteria, the mineral medium of Schlegel et al. (31) was used as the standard mineral (SM) medium. For heterotrophic growth, this medium was supplemented with carbon sources $(0.5 \%$ sugar and $0.2 \%$ organic acid, unless otherwise stated). For chemolithoautotrophic growth, $0.05 \% \mathrm{NaHCO}_{3}$ was added, and the cultures were incubated under an atmosphere of $10 \% \mathrm{O}_{2}-10 \% \mathrm{CO}_{2}-80 \% \mathrm{H}_{2}$. During cultivation in a model 10-liter Biostat fermentor (Braun AG, Melsungen, West Germany), the $\mathrm{O}_{2}$ partial pressure was increased to $25 \%$. Nutrient broth (NB; Difco 
TABLE 1. List of strains studied ${ }^{a}$

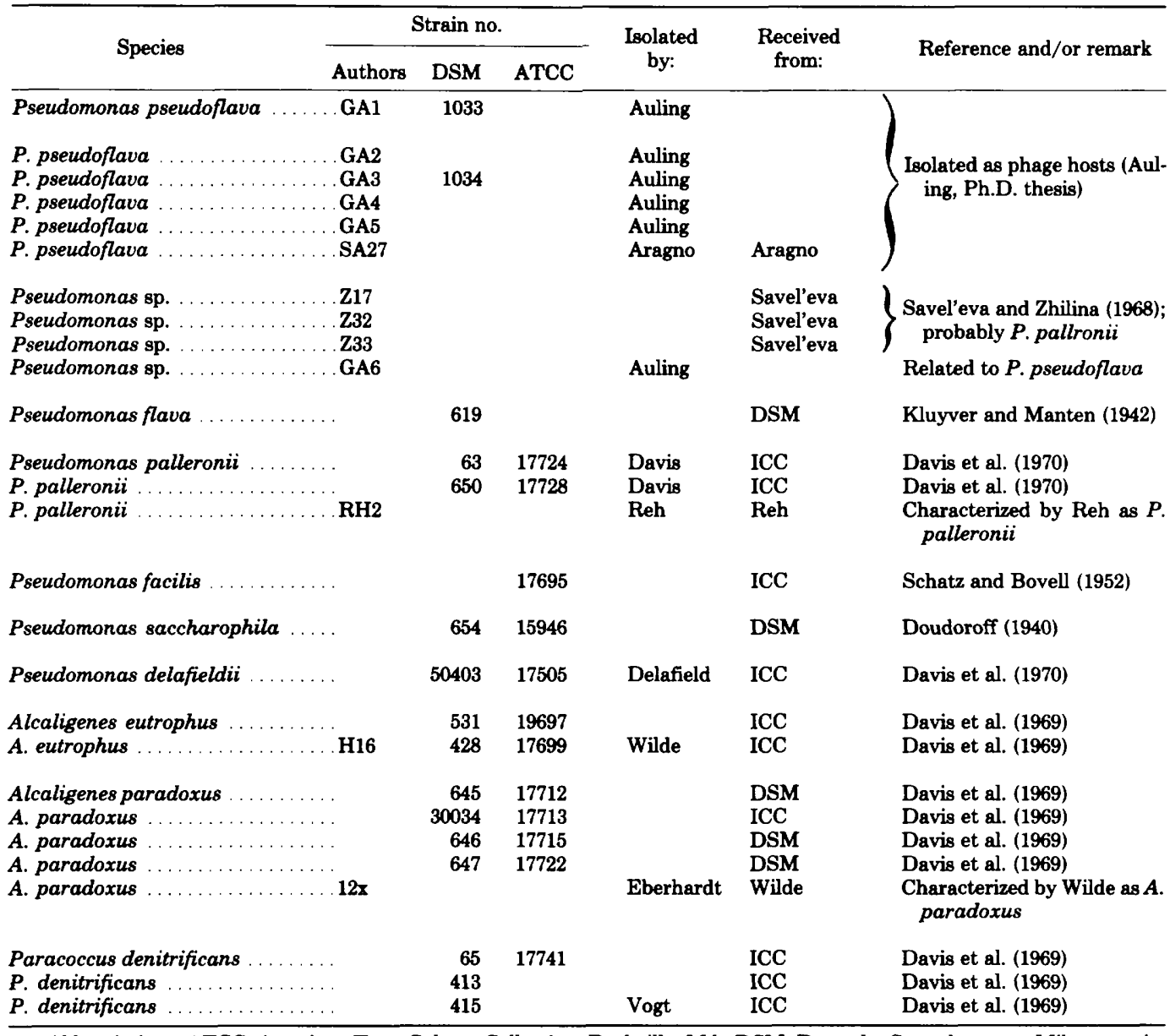

a Abbreviations: ATCC, American Type Culture Collection, Rockville, Md.; DSM, Deutsche Sammlung von Mikroorganismen, Göttingen, Federal Republic of Germany; ICC, Institute's (Göttingen) Culture Collection.

Laboratories, Detroit, Mich.) was used as the nutritionally complex medium.

The following mineral medium was used for maintenance of strains: $0.05 \% \mathrm{KH}_{2} \mathrm{PO}_{4} ; 0.10 \% \mathrm{NaCl} ; 0.02 \%$ $\mathrm{MgSO}_{4} \cdot 7 \mathrm{H}_{2} \mathrm{O} ; \quad 0.05 \% \quad \mathrm{NaHCO}_{3} ; \quad 0.05 \% \quad \mathrm{Fe}\left(\mathrm{NH}_{4}\right)_{2-}$ $\mathrm{SO}_{4} \cdot 6 \mathrm{H}_{2} \mathrm{O}$, and $1.50 \%$ agar.

Morphology and production of reserve materials. The mode of flagellation was studied by electron microscopy. Cells were grown in NB, fructose-SM medium, and in SM medium under an atmosphere of $10 \% \mathrm{O}_{2}-10 \% \mathrm{CO}_{2}-80 \% \mathrm{H}_{2}$; cells from different stages of the growth curve were inspected.

For polymyxin B treatment, cells of $P$. pseudoflava GA3 were grown in xylose-SM medium, harvested in the logarithmic phase of growth by centrifugation, and suspended in $10 \mathrm{mM}$ tris(hydroxymethyl)aminomethane-hydrochloride buffer, $\mathrm{pH}$ 7.2. After the suspension was adjusted to a concentration of $2 \times 10^{8}$ cells per $\mathrm{ml}, 5$-ml quantities of the suspension were incubated with 0 or $5 \mu \mathrm{g}$ of polymyxin $B$ sulfate (Pfizer Inc., New York, N.Y.) for $35 \mathrm{~min}$.
For negative staining, the cells were suspended in $\mathbf{0 . 2}$ $\mathrm{ml}$ of $10 \mathrm{mM}$ tris(hydroxymethyl)aminomethane-hydrochloride buffer. All electron microscopy techniques were performed by the methods of Walther-Mauruschat et al. (36). Quantitative determination of the poly- $\beta$-hydroxybutyric acid (PHB) content of the cells and the isolation of PHB were carried out by the procedures of Jüttner et al. (14). The infrared spectrum of pure PHB from strain GA3 was made from a film of PHB on solid $\mathrm{NaCl}$ in a Unicam-SP 100 infrared spectrophotometer.

Polysaccharide was isolated by extraction of $30 \mathrm{~g}$ of freeze-dried, autotrophically grown cells of strain GA3 by a slight modification of the procedures of Sigal et al. (33) and Zevenhuizen and Ebbink (38): extraction with $30 \% \mathrm{NaOH}$ for $1 \mathrm{~h}$ at $100^{\circ} \mathrm{C}$, precipitation with $96 \%$ ethanol, and removal of impurities by extraction with chloroform and precipitation with $3 \mathrm{M}$ trichloroacetic acid. The percentage of glucose liberated upon acid hydrolysis of the polysaccharide in $2 \mathrm{~N} \mathrm{H}_{2} \mathrm{SO}_{4}$ for $12 \mathrm{~h}$ at $100^{\circ} \mathrm{C}$ was determined with 
glucose oxidase (2). The neutralized hydrolysate was co-chromatographed with reference sugars on thinlayer cellulose in $n$-propanol-water (85:15) as the solvent (34). The infrared spectra of the polysaccharides from strain GA3 and from Arthrobacter sp. strain 23 were made in solid $\mathrm{KBr}$; the absorbance spectra of the iodine complexes were measured by the method of Ghosh and Preiss (10).

Nutritional properties. Substrate utilization tests were done in SM medium both by replica plating according to Stanier et al. (35) and by a multipoint inoculator (Denley-Tech. Ltd., Great Britain). Growth was recorded visually after 2,4 , and 6 days. Questionable growth on plates was further examined in liquid culture by turbidimetry.

Methods for determining biochemical features. The hydrolysis of starch, urea, exogenous PHB, and Tween 80, the Gram reaction (using the Hucker modification), and the presence of catalase and oxidase were determined by the procedures of Cowan (3). The presence of catalase in starved cells in $0.05 \mathrm{M}$ phosphate buffer (pH 7.0) was also determined by measurement of the $\mathrm{O}_{2}$ produced from $12.5 \mathrm{M} \mathrm{H}_{2} \mathrm{O}_{2}$ in a closed system with an oxygen electrode (Yellow Springs Instruments Co., Inc.). Indole formation, digestion of casein, and reduction of nitrate to nitrite were determined by the methods of Gordon et al. (11). The tests for nitrogen source, gas formation from glucose, hexadecane utilization, and denitrification were carried out by the methods of Stanier et al. (35). The hydrolysis of gelatin was tested for by the method of Schubert (32), and the hydrolysis of esculin was determined in SM medium after the addition of $0.05 \%$ $\mathrm{Fe}-\mathrm{NH}_{4}$-citrate and $0.1 \%$ esculin. For the detection of carbohydrate cleavage, cultures in the following medium incubated at $30^{\circ} \mathrm{C}$ were observed for 6 days: $\left(\mathrm{NH}_{4}\right)_{2} \mathrm{HPO}_{4}, 1.0 \mathrm{~g} ; \mathrm{KCl}, 0.2 \mathrm{~g} ; \mathrm{MgSO}_{4} \cdot 7 \mathrm{H}_{2} \mathrm{O}, 0.2 \mathrm{~g}$; $\mathrm{CaCl}_{2} \cdot 2 \mathrm{H}_{2} \mathrm{O}, 10 \mathrm{mg}$; Fe-NH4-citrate, $5 \mathrm{mg}$; and $4 \mathrm{ml}$ of $0.2 \%$ bromocresol purple in $1,000 \mathrm{ml}$ of water; $\mathrm{pH}$ 7.0. The accumulation of colored by-products of metabolism was tested for in SM medium supplemented with $0.2 \%$ each of tryptophan, tyrosine, and phenylalanine.

Growth parameters and chemolithoautotrophy. The temperature ranges for growth were examined on NB agar slants. The temperature optimum for growth was determined in liquid SM medium in 1-liter fluted Erlenmeyer flasks agitated by magnetic stirring in thermocontrolled water baths. The $\mathrm{pH}$ dependence of growth was examined by using either NB titrated with $\mathrm{HCl}$ or $\mathrm{NaOH}$ before sterilization by filtration or lactate mineral medium buffered with phosphate.

Autotrophic growth of the $P$. pseudoflava strains was studied in 10-liter Biostat fermentors. The gaseous substrates were supplied with Wösthoff $1 \mathrm{M} / 300 \mathrm{a}$ gas pumps (Wösthoff OHG, Bochum, West Germany). Overall gas uptake was calculated from the differences of gas input and output as measured with an Elster gas counter (Elster AG, Mainz, West Germany).

Resistance against temperate bacteriophages, bacteriostatic agents, and antibiotics. Phage typing was done by spotting a lysate of each phage containing $10^{6}$ to $10^{8}$ plaque-forming units per $\mathrm{ml}$ on double-layered SM agar plates inoculated with the bacterial strains to be tested. The phages had been isolated from the strains here placed in $P$. pseudoflava (G. Auling, Ph.D. thesis, University of Göttingen, 1975). The activities of these phages were tested on fructose-SM or gluconate-SM medium and on SM medium under an atmosphere of $10 \% \mathrm{O}_{2}-10 \% \mathrm{CO}_{2}-80 \%$ $\mathrm{H}_{2}$ because the phages had originally been isolated under autotrophic conditions.

Inhibition of growth by bacteriostatic agents was examined in 5-ml cultures of fructose-SM or gluconate-SM medium after 6 days of incubation in a tube incubator at $30^{\circ} \mathrm{C}$. The initial optical density at 546 $\mathrm{nm}$ was 0.1 to 0.3 .

Resistance against 10 selected antibiotics was tested with a modified agar diffusion test, using sugar-SM or gluconate-SM agar plates with top layers of soft agar $(3 \mathrm{ml}$ ) inoculated with $0.4 \mathrm{ml}$ of 48 -h-old cultures. Five disks (Oxoid) with different antibiotics were placed on each plate, and susceptibility was determined visually after 36 or $48 \mathrm{~h}$ of incubation at $30^{\circ} \mathrm{C}$.

Analysis of pigments and cytochromes. For the identification of pigments, freeze-dried cells were extracted in the dark with a mixture of acetone-methanol $(1: 1, \mathrm{vol} / \mathrm{vol})$ under nitrogen at room temperature for at least $20 \mathrm{~h}$. On the assumption that the pigments were carotenoids, the pigment extract was saponified with $5 \% \mathrm{KOH}$ in methanol in the usual manner (18). The pigments were separated on Kieselgel G (type 60, Merck, Darmstadt, West Germany) thin-layer plates with $30 \%$ acetone in petroleum ether (bp, 40 to $\left.60^{\circ} \mathrm{C}\right) . R_{f}$ values were determined on Schleicher and Schüll no. 287 paper (with kieselguhr filler) by the method of Jensen and Liaaen-Jensen (13).

Cytochromes were analyzed as described by Probst and Schlegel (26). Extractions of cytochromes with $50 \%$ pyridine in $0.1 \mathrm{~N} \mathrm{NaOH} \mathrm{(37)} \mathrm{were} \mathrm{done} \mathrm{for} \mathrm{the}$ detection of small portions of cytochrome $d$ (cytochrome $a_{2}$ ) in addition to cytochrome $a a_{3}$ or cytochrome $a_{1}(9)$.

Serological methods. Formalin $(0.25 \%$, vol/ vol)-killed cells from three strains of $P$. pseudoflava (GA1, GA2, GA3) were used for the immunization of rabbits (17). For agglutination tests, $0.5 \mathrm{ml}$ of washed cells (optical density at $546 \mathrm{~nm}$ of 4.0 ) was added to $0.5 \mathrm{ml}$ of twofold dilutions of antiserum in $0.9 \% \mathrm{NaCl}$, mixed, and incubated at $37^{\circ} \mathrm{C}$; the agglutination titer was recorded after 2, 4, and $24 \mathrm{~h}$. Precipitates were judged as positive when the supernatant was clear due to agglutination and as compared to the control. Ouchterlony-type double-diffusion tests with bacterial homogenates were performed by the procedures of Ohara et al. (24).

DNA base composition and DNA reassociation. Isolation of DNA and estimation of the mole percent guanine plus cytosine $(G+C)$ in the DNA by the thermal denaturation method were performed by the procedures of Marmur and Doty (21). The buoyant density of the DNA was measured in a Beckmann model $\mathrm{E}$ analytical ultracentrifuge with and without bacteriophage $\lambda$ DNA as a reference (20). DNA-DNA renaturation was done in $0.5 \mathrm{M}$ sodium phosphate buffer ( $\mathrm{pH} \mathrm{7.0)}$ in a Gilford spectrophotometer. Formamide at a final concentration of $25 \%$ ( $\mathrm{vol} / \mathrm{vol}$ ) was 
added to lower the optimal renaturation temperature. The degree of binding was calculated by the method of DeLey et al. (6).

\section{RESULTS}

Morphological features of $P$. pseudoflava. All of the $P$. pseudoflava strains were gram negative. After treatment with polymyxin $B$ and as revealed by electron microscopy (Fig. 1), rodlike projections appeared on the cell surface. These blebs are characteristic of the action of polymyxin $B$ on gram-negative bacteria (19).

Electron micrographs of the cells of the strains here placed in $P$. pseudoflava have already been published (30). The rod-shaped cells had an oval form with a length of $1.0 \mu \mathrm{m}$ after cell division. The average width of the cells was $0.5 \mu \mathrm{m}$. During the stationary phase of growth, the average cell length reached $2.5 \mu \mathrm{m}$. The cells were motile mainly during the logarithmic growth phase; motility was due to a single polar or subpolar flagellum. In rare cases, cells with two polar flagella at one pole have been observed. The flagella had a length of 3 to $5 \mu \mathrm{m}$ and an average diameter of $15 \mathrm{~nm}$. The formation of flagella was independent of the nutrients but was dependent on the growth phase.

A second type of protein appendage, pili, was observed. The pili appeared more flexible than the flagella and had a length four to five times that of the cells and a diameter of 6 to $9 \mathrm{~nm}$.

On NB agar, the colonies were 2 to $4 \mathrm{~mm}$ in diameter (3 days) and slightly irregular in shape with an undulate margin. On xylose-SM agar, the colonies were smaller $(2 \mathrm{~mm})$ than on NB agar and showed a convex central elevation; slime formation was never observed on NB or SM medium or on a combination of these media. On SM plates after autotrophic incubation, the colonies were flat with an entire margin. The yellow pigmentation of the new strains was more intensive on sugar-SM plates than on NB plates. With phenol as a substrate, the colonies were nearly colorless.

Nutritional and biochemical properties. The new strains were examined for growth on 107 organic compounds. P. flava DSM 619 and strains of $P$. palleronii and Alcaligenes para-

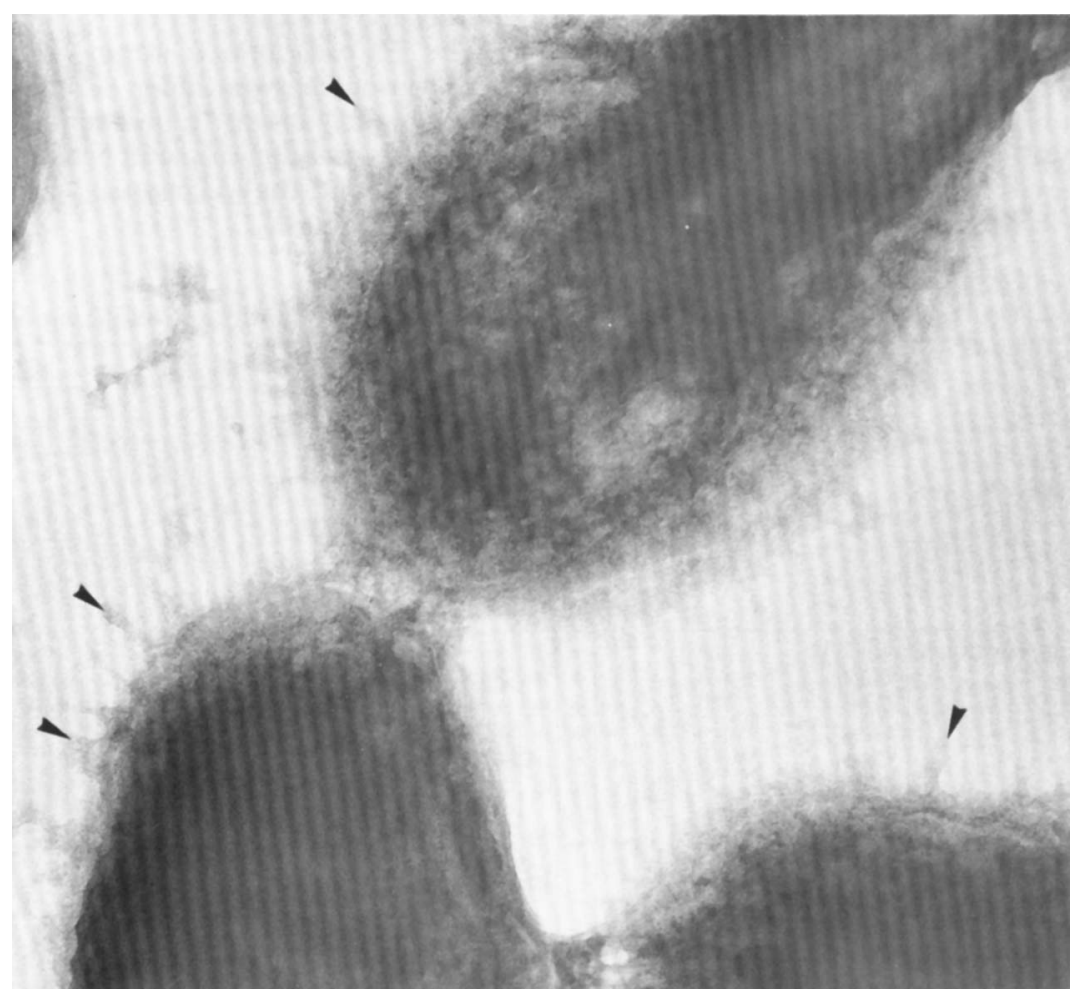

FIG. 1. Polymyxin B treatment of P.pseudoflava GA3. Five-milliliter suspensions of cells with a titer of 2 $\times 10^{8}$ colony-forming units per $\mathrm{ml}$ were incubated with $5 \mu \mathrm{g}$ of polymyxin $B$ sulfate at $37^{\circ} \mathrm{C}$ for $35 \mathrm{~min}$. For negative staining, the cells were suspended in $0.2 \mathrm{ml}$ of $10 \mathrm{mM}$ tris(hydroxymethyl)aminomethane-hydrochloride ( $p H$ 7.2). $\times 95,000$. 
doxus were included for comparison. Among the substrates tested, 22 organic compounds were found appropriate to differentiate between the species of yellow-pigmented hydrogen bacteria known so far. A scheme for their rapid identification with a focus on $P$. pseudoflava and $P$. flava is presented in Table 2.

The strains of $P$. pseudoflava proved to be rather nutritionally versatile: 42 of the 107 organic compounds tested were utilized by all of the $P$. pseudoflava strains, and 25 of the compounds could not be used by any strain. The substrates utilized by all of the strains included: the carbohydrates and sugar derivatives $D-(+)$ glucose, $D-(-)$-fructose, $L-(+)$-arabinose, $D-(+)$ galactose, $D-(+)$-xylose, $D$-mannose, saccharose, D- $(+)$-trehalose, cellobiose, maltose, D-(-)-mannitol, meso-inositol, glycerol, and gluconate; the miscellaneous organic acids and alcohols pyruvate, acetate, lactate, $D$-malate, citrate, fumarate, $\beta$-hydroxybutyrate, ethanolamine, $p$-hydroxybenzoate, shikimic acid, quinate, cisaconitate, and phenol; and the amino acids L-alanine, $\mathrm{D}$-alanine, L-leucine, L-isoleucine, L-asparagine, L-aspartate, L-glutamate, L-glutamine, L-ornithine, L-lysine, L-proline, L-histidine, L-phenylalanine, L-tyrosine, and L-tryptophan.

The following were not utilized as sole carbon sources: $D-(+)$-fucose, $D-(+)$-ribose, $D(-)$-arabinose, 2-keto-D-gluconate, formate, malonate, mesaconate, citraconate, oxalate, meso-tartrate, propionate, caproate, benzoate, salicylate, an- thranilate, nicotinate, pantothenate, 2-methyl-2propanol, 2,3-butylene glycol, allantoin, uric acid, citrulline, L-methionine, L-threonine, and DL-threonine.

The other 20 organic compounds tested either permitted scanty growth or were variably utilized by the strains of $P$. pseudoflava. These compounds were: $\mathrm{L}-(+)$-rhamnose, isocitrate, butyrate, L-(+)-tartrate, D-(-)-tartrate, $n$-valerate, isovalerate, pimelate, suberate, aconitate, glycolate, DL-glycerate, D-saccharate, $\alpha$-ketoglutarate, ethanol, $n$-propanol, $n$-butanol, L-glycine, $\mathrm{L}$-valine, and L-arginine.

The nutritional pattern of the strains of $P$. pseudoflava was very similar to that of $P$. flava. In comparison with $P$. pseudoflava, the substrate spectrum of $P$. flava was more restricted in that the latter failed to grow on $\mathrm{D}-(+)$-xylose, cis-aconitate, $p$-hydroxybenzoate, phenol, ethanol, ethanolamine, DL-glycerate, L-leucine, L-isoleucine, L-lysine, L-asparagine, L-tryptophan, $\mathrm{L}$ tyrosine, and L-phenylalanine. So far, no organic compound has been found that allows growth of $P$. flava but that does not support the growth of all of the presently known strains of $P$. pseudoflava.

The $P$. pseudoflava strains produced acid from various sugars under aerobic conditions. This property seems to be a characteristic feature of $P$. pseudoflava, one useful for differentiating among the yellow-pigmented hydrogen bacteria (Table 3 ).

TABIE 2. Utilization of various substrates by the yellow-pigmented, hydrogen-oxidizing bacteria

\begin{tabular}{|c|c|c|c|c|c|c|c|c|c|c|c|c|c|c|c|c|c|c|c|c|c|c|c|}
\hline & & \multicolumn{22}{|c|}{ Utilization $^{\alpha}$ of: } \\
\hline Species & Strain & 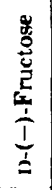 & $\begin{array}{l}\frac{1}{0} \\
\frac{0}{2} \\
\frac{3}{1} \\
\frac{1}{ \pm} \\
\vdots\end{array}$ & 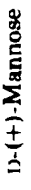 & 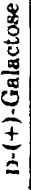 & 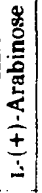 & 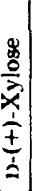 & 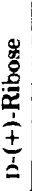 & 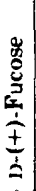 & 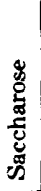 & 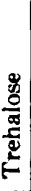 & 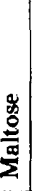 & 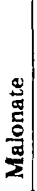 & 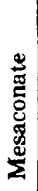 & 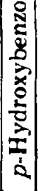 & 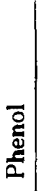 & \begin{tabular}{l}
$\stackrel{\Xi}{\Xi}$ \\
\multirow{2}{*}{} \\
$\vdots$ \\
$\vdots$
\end{tabular} & 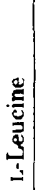 & 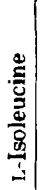 & 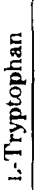 & & 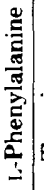 & ـ \\
\hline Pseudomonas pseudoflava & GA1 & + & + & + & + & + & + & - & - & + & + & + & - & - & + & + & + & + & + & + & + & + & + \\
\hline$P$. pseudoflava & GA2 & + & + & + & + & + & + & - & - & + & + & + & - & - & + & + & + & + & + & + & + & + & + \\
\hline P. pseudoflava & GA3 & + & + & + & + & + & + & - & - & + & + & + & - & - & + & + & + & + & + & + & + & + & + \\
\hline P. pseudoflava & GA4 & + & + & + & + & + & + & - & - & + & + & + & - & - & + & + & + & + & + & + & + & + & + \\
\hline P. pseudoflava & GA5 & + & + & + & + & + & + & - & - & + & + & + & - & - & + & + & + & + & + & + & + & + & + \\
\hline P. preudoflava & SA27 & + & + & + & + & + & + & - & - & + & + & + & - & - & + & + & + & + & +1 & + & + & + & + \\
\hline Pseudomonas flava & DSM 619 & + & + & + & + & + & - & - & - & + & + & + & - & - & - & - & - & - & - & - & - & - & - \\
\hline$P_{\text {seudomonas palleronii }}$ & ATCC 17724 & - & - & - & - & - & - & - & - & - & - & - & - & - & + & + & -1 & + & + & + & + & + & + \\
\hline Alcaligenes paradoxus & ATCC 17713 & + & + & + & + & + & + & + & + & - & - & - & + & + & + & - & - & + & + & + & + & + & + \\
\hline $\begin{array}{l}\text { "Corvnebacterium" auto- } \\
\text { trophicumb }\end{array}$ & & $+1-$ & - & - & - & - & - & - & & 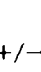 & - & - & - & & & & -- & - & & & & - & \\
\hline
\end{tabular}

"Symbols: + , positive result; - , negative result; \pm , variable result.

"Data for 35 strains of "Corynebacterium" autotrophicum from Wiegel (personal communication). "Corynebacterium" autotrophicum will be reclassified by Wiegel et al. (paper in preparation) on the basis of its gram-negative character. 
TABLE 3. Production of acid from carbohydrates by yellow-pigmented, hydrogen-oxidizing bacteria under aerobic growth conditions

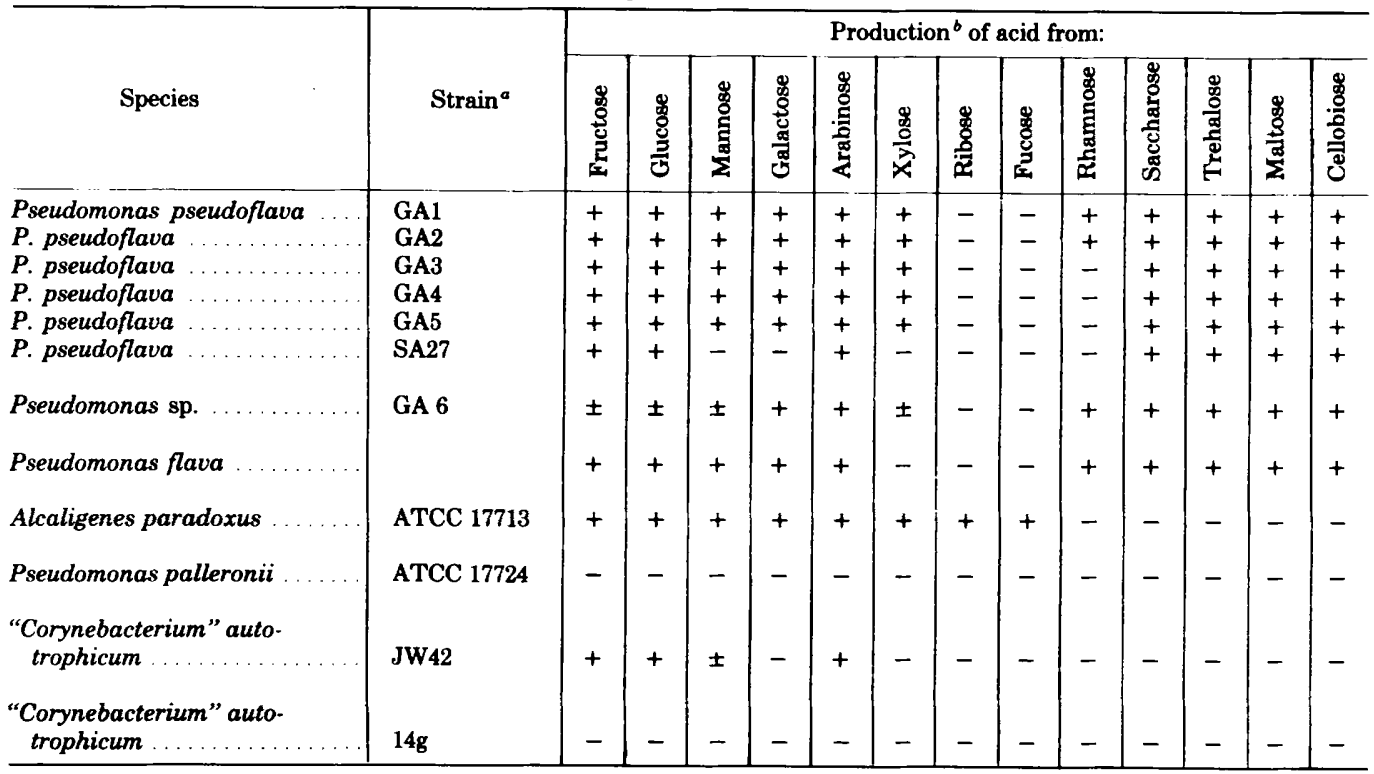

a Abbreviation: ATCC, American Type Culture Collection, Rockville, Md.

${ }^{\circ}$ Symbols: + , positive result; - , negative result; \pm , variable result.

TABLE 4. Biochemical features of Pseudomonas pseudoflava and reference hydrogen bacteria ${ }^{a}$

\begin{tabular}{|c|c|c|c|c|c|c|c|c|c|c|c|c|c|c|c|c|c|c|c|c|c|c|c|c|}
\hline \multirow[b]{2}{*}{ Strain $^{b}$} & \multicolumn{7}{|c|}{ Hydrolysis of: } & \multicolumn{4}{|c|}{ Utilization of: } & \multicolumn{3}{|c|}{$\begin{array}{c}\text { Reduc- } \\
\text { tion of ni- } \\
\text { trate to } \\
\text { nitrite: }\end{array}$} & \multicolumn{3}{|c|}{$\begin{array}{l}\text { Denitrifi- } \\
\text { cation } \\
\text { with: }\end{array}$} & \multicolumn{4}{|c|}{$\begin{array}{l}\text { Production } \\
\text { of: }\end{array}$} & \multicolumn{3}{|c|}{$\begin{array}{l}\text { Produc- } \\
\text { tion of } \\
\text { pigment } \\
\text { from: }\end{array}$} \\
\hline & 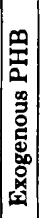 & 额 & 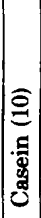 & 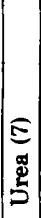 & 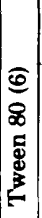 & 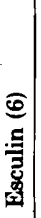 & $\begin{array}{l}E \\
\frac{s}{0} \\
\text { s } \\
\text { v }\end{array}$ & $z^{N}$ & 离 & 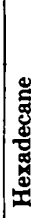 & $\pi$ & $\Xi$ & 悉 & $\widehat{\infty}$ & 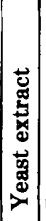 & 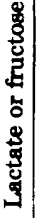 & 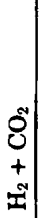 & 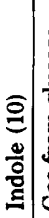 & 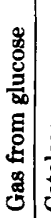 & 总 & $\mid$ & 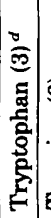 & 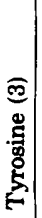 & 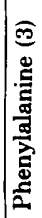 \\
\hline $\begin{array}{l}\text { Pseudomonas pseudoflava GA1 } \\
\text { P. pseudoflava GA2 } \ldots \ldots \ldots \\
\text { P. pseudoflava GA3 } \ldots \ldots \ldots \\
\text { P. pseudoflava GA4 } \\
\text { P. pseudoflava GA5 } \ldots \ldots \ldots \\
\text { P. pseudoflava SA27 } \ldots \ldots \ldots\end{array}$ & $\begin{array}{l}- \\
- \\
- \\
- \\
- \\
-\end{array}$ & $\begin{array}{l}\overline{-} \\
\overline{-} \\
\overline{-} \\
\overline{-}\end{array}$ & $\begin{array}{l}- \\
- \\
- \\
- \\
- \\
-\end{array}$ & $\begin{array}{l}- \\
- \\
- \\
- \\
-\end{array}$ & $\begin{array}{l}+ \\
+ \\
+ \\
+ \\
+ \\
+\end{array}$ & $\begin{array}{l}- \\
- \\
- \\
- \\
- \\
-\end{array}$ & $\begin{array}{l}- \\
- \\
- \\
- \\
- \\
-\end{array}$ & $\begin{array}{l}- \\
- \\
- \\
- \\
-\end{array}$ & $\begin{array}{l}+ \\
+ \\
+ \\
+ \\
+ \\
+\end{array}$ & $\begin{array}{l}- \\
- \\
- \\
- \\
-\end{array}$ & $\begin{array}{l}+ \\
+ \\
+ \\
+ \\
+ \\
+\end{array}$ & $\begin{array}{l}+ \\
- \\
+ \\
- \\
-\end{array}$ & $\begin{array}{l}- \\
- \\
- \\
- \\
- \\
-\end{array}$ & $\begin{array}{l}- \\
- \\
- \\
- \\
- \\
-\end{array}$ & $\begin{array}{l}+ \\
+ \\
+ \\
+ \\
+ \\
+\end{array}$ & $\begin{array}{l}+ \\
+ \\
+ \\
+ \\
+ \\
+\end{array}$ & $\begin{array}{l} \pm \\
\pm\end{array}$ & $\begin{array}{l}- \\
- \\
- \\
- \\
- \\
-\end{array}$ & $\begin{array}{l}- \\
- \\
- \\
- \\
- \\
-\end{array}$ & $\begin{array}{l} \pm \\
\pm \\
\pm \\
\pm \\
\pm \\
\pm\end{array}$ & $\begin{array}{l}+ \\
+ \\
+ \\
+ \\
+ \\
+\end{array}$ & $\begin{array}{l}+ \\
+ \\
+ \\
+ \\
+ \\
+\end{array}$ & $\begin{array}{l}- \\
- \\
- \\
- \\
- \\
-\end{array}$ & $\begin{array}{l}- \\
- \\
- \\
- \\
- \\
-\end{array}$ \\
\hline Pseudomonas flava & - & - & - & - & - & - & - & - & + & - & - & - & - & - & - & - & - & - & $-=$ & \pm & + & - & - & - \\
\hline Pseudomonas palleronii ATCC 17724 & - & - & - & - & + & & - & - & + & - & + & - & - & - & - & - & - & - & $-1=$ & \pm & + & - & - & - \\
\hline Alcaligenes paradoxus ATCC 17722 & + & - & - & + & + & - & - & - & + & - & + & + & + & + & - & - & - & - & -1 & + & + & - & - & - \\
\hline
\end{tabular}

${ }^{a}$ Symbols: + , positive result; - , negative result; \pm , variable result.

${ }^{\circ}$ ATCC, American Type Culture Collection, Rockville, Md.

c Numbers in parentheses refer to days of incubation.

${ }^{d} \mathrm{~A}$ brown pigment is produced by positive strains.

Further biochemical features of the $P$. pseudoflava strains and of reference strains of certain other gram-negative hydrogen bacteria are recorded in Table 4. The catalase reaction was negative for all of the $P$. pseudoflava strains when tested by the method of Cowan (3). Only by a sensitive micromethod using an oxygen electrode in a closed system was a weak catalase reaction found in the strains of $P$. pseudoflava. During growth on tryptophan in liquid SM me- 
dium and on plates, all strains of $P$. pseudoflava developed a brown to black color after 2 to 5 days of incubation. As determined chromatographically, these colored by-products of metabolism were not identical to anthranilate or protocatechuate.

Denitrification by the strains of $P$. pseudoflava occurred not only in the medium of Stanier et al. (35), which contains glycerol and yeast extract, but also with lactate or fructose plus glycerol in SM medium supplemented with 10 g of either $\mathrm{NaNO}_{3}$ or $\mathrm{KNO}_{3}$ per liter. Growth of strains GA3 and GA4 on the basis of nitrate respiration in SM medium with $90 \%$ hydrogen and $10 \%$ carbon dioxide was slow. Surprisingly, many strains of $P$. pseudoflava have recently been isolated by enrichment under these conditions (M. Aragno, personal communication).

Growth parameters and chemolithoautotrophy. In contrast to $P$. flava, which cannot grow at $37^{\circ} \mathrm{C}$, all strains of $P$. pseudoflava were able to grow at 40 and $41^{\circ} \mathrm{C}$, and some could grow at $43^{\circ} \mathrm{C}$. The temperature for optimum growth of $P$. pseudoflava GA3 under autotrophic conditions was 1 to $2 \mathrm{C}$ degrees lower than that for growth under heterotrophic conditions. When the growth rates $\left(\right.$ hour $\left.^{-1}\right)$ were plotted against temperature, the peak of the curve for growth on $\mathrm{H}_{2}$ plus $\mathrm{CO}_{2}$ was sharper than that for growth on glucose (Fig. 2). How-

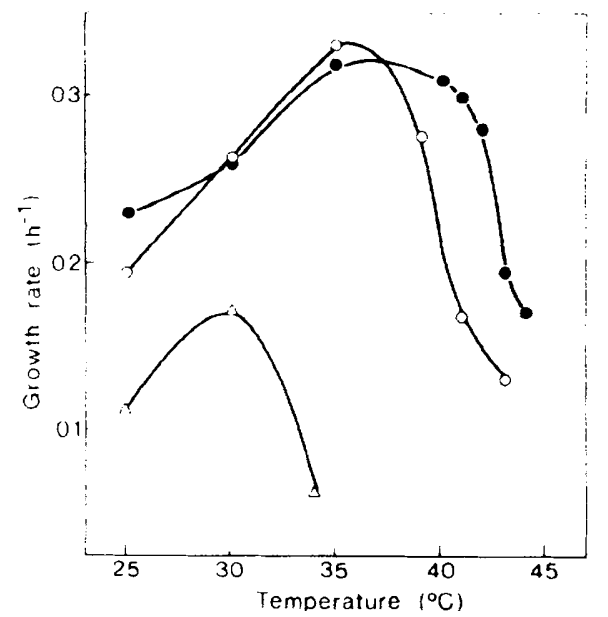

FIG. 2. Comparison of optimum growth temperatures of P. pseudoflava GA3 and P. flava. Growth rates were measured in baffled 1-liter Erlenmeyer flasks, each containing $100 \mathrm{ml}$ of liquid medium and agitated by magnetic stirring $(300 \mathrm{rpm})$ in a water bath. Growth was followed turbidimetrically starting with an initial optical density at $546 \mathrm{~nm}$ of 0.05 and going up to 5.0. Symbols: , strain GA3 grown with $0.5 \%$ glucose; $O$, strain GA3 grown under an atmosphere of $10 \% \mathrm{O}_{2}-10 \% \mathrm{CO}_{2}-80 \% \mathrm{H}_{2} ; \triangle$, P. flava grown with $0.5 \%$ fructose. ever, both optima were substantially higher than the optimum temperature of heterotrophically grown cultures of $P$. flava. A selective enrichment procedure for strains of $P$. pseudoflava might be possible on the basis of their elevated temperature for optimum growth.

The $\mathrm{pH}$ for optimum growth of the strains of $P$. pseudoflava in NB medium was about 7.5; in lactate-SM medium, it was about 7.3; and in autotrophic medium, it was about 7.0.

All strains of $P$. pseudoflava were found to be relatively fast growing, with doubling times of 2 to $3 \mathrm{~h}$ during autotrophic growth at 35 or $37^{\circ} \mathrm{C}$. In the logarithmic phase of growth, they were determined by cell analysis to be free from PHB and polysaccharide storage material. The strains proved to be tolerant to 20 to $25 \%$ oxygen in the incubation atmosphere.

Ultrastructure and cytoplasmic inclusions. Ultrathin sections of cells of $P$. pseudoflava GA3 revealed a cell wall characteristic of the gram-negative type and intracytoplasmic inclusions of PHB, polysaccharide, and polyphosphate (Fig. 3).

As confirmed by quantitative analyses (14), the PHB content ( 3 to $20 \%$ ) varied with cultural conditions; PHB was partially consumed during endogenous respiration and starvation. The infrared spectrum of pure $\mathrm{PHB}$ isolated from $P$. pseudoflava GA3 was identical to that of PHB from Alcaligenes eutrophus H16. There was no trace of any neutral lipids.

Polysaccharide was isolated from autotrophically grown cells; it was 96\% pure (anthrone reagent), and its glucose content after acid hydrolysis was $88 \%$ (enzymatic analysis). Glucose was also demonstrated as the sole carbon compound of the neutralized polysaccharide hydrolysate by co-chromatography with reference monosaccharides (34). The visible absorption spectra of the iodine complexes (10) and the infrared spectra (16) of the polysaccharide from $P$. pseudoflava GA3 and of a reference sample of glycogen from Arthrobacter sp. strain 23 were identical. Pure Arthrobacter glycogen was prepared by $H$.-J. Knackmuss. From these analyzed data and from the ultrastructural observations (further details of ultrastructure are given by Walther-Mauruschat et al. [36]), it is concluded that the polyglucan present in $P$. pseudoflava GA3 is glycogen.

Cytochromes and other pigments. Cytochromes of the $a, b$, and $c$ types were found in the membrane fractions of all of the P. pseudoflava strains tested (Fig. 4A, spectrum a). Cytochromes of the $c$ type were also found in the supernatant fractions. After heterotrophic growth, the cytochrome pattern was the same in cells harvested from either the logarithmic 


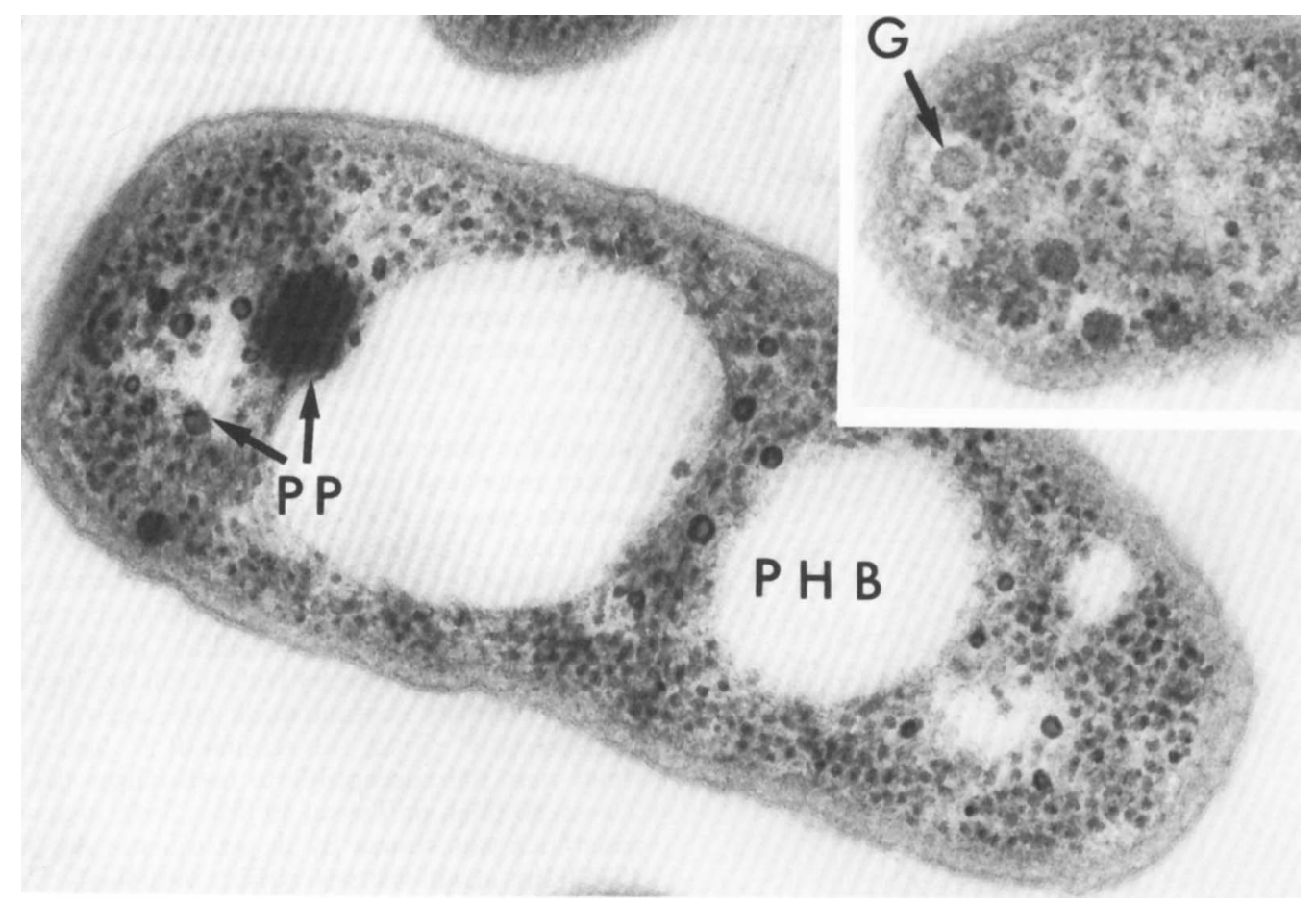

FIG. 3. Ultrathin section of P. pseudoflava GA3. PP, Polyphosphate; PHB, poly- $\beta$-hydroxybutyric acid; $G$, glycogen-like polysaccharide. $\times 80,000$.

or the stationary growth phase. However, after autotrophic growth, the ratio of the concentration of the $b$-type and the $c$-type cytochromes varied from strain to strain and, in strain GA1, it was the reciprocal of that after heterotrophic growth (Fig. 4A, spectrum b). For comparison, cytochromes of additional yellow-pigmented, gram-negative hydrogen bacteria whose taxonomic position has been discussed by Davis et al. $(4,5)$ were analyzed as well, because the presence of a cytochrome $d\left(a_{2}\right)$ has been regarded (4) as typical and exclusive for Alcaligenes paradoxus among the gram-negative hydrogen bacteria. Difference spectra of membrane fractions from heterotrophically grown cells of $P$. flava, $P$. palleronii ATCC 17724, and $A$. paradoxus ATCC 17713, harvested in the logarithmic growth phase, were identical to those for heterotrophically grown cells of strains of $P$. pseudoflava. A cytochrome $d\left(a_{2}\right)$ was not detected in $A$. paradoxus ATCC 17713 by the usual room temperature difference spectra (Fig. 4A, spectrum c).

Pyridine- $\mathrm{NaOH}$ extracts of heterotrophically grown cells of all $P$. pseudoflava strains showed no trace of a cytochrome $d$ (Fig. 4B, spectrum a). Due to shifts of the $\alpha$-peak of cytochromes $a_{1}$ and $a a_{3}$ to $587 \mathrm{~nm}$ by formation of pyridine hemochromes (9), small amounts of cytochrome $d$ should have been detected in this way. Cytochrome $d$ was not found by this method in heterotrophically grown cells (log phase) of $A$. paradoxus ATCC 17713, P. palleronii ATCC 17724, and $P$. flava (Fig. 4B, spectrum c). However, small amounts of cytochrome $d$ were found in autotrophically grown cells of $P$. pseudoflava GA3 after pyridine- $\mathrm{NaOH}$ extraction of freezedried cells that had been harvested in the stationary phase of growth (Fig. 4B, spectrum b).

During the isolation of the yellow pigments, only minor portions from the saponified mixtures could be transferred from the acetonemethanol phase to diethyl ether. The remaining pigments required acidification for transfer into the diethyl ether epiphase. Because of this partition behavior, the yellow pigments will be referred to as "neutral" or "acidic" components. The isolated pigments of all strains of P. pseudoflava have absorption maxima in acetone at (400), 423, and $446 \mathrm{~nm}$ (Table 5), similar to those of $P$. palleronii and $A$. paradoxus but different from those of $P$. flava (5). Apparently the majority of these bacteria contain a mixture of two different pigments (D. H. Davis, Ph.D. thesis, 1967). In contrast to this, $P$. pseudoflava probably synthesizes from one basic compound 
a series of pigments, the components of which are characterized only by their different polarities (see $R_{f}$ values, Table 5).

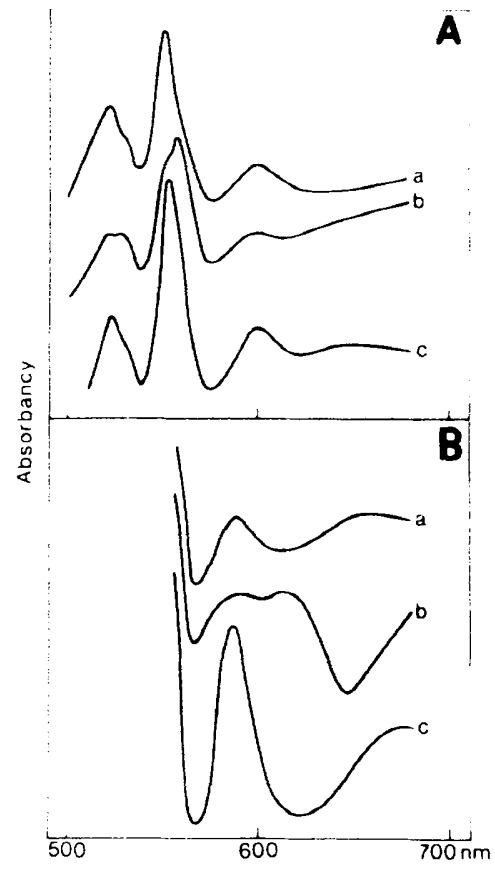

Fig. 4. Cytochrome difference spectra of P. pseudoflava and other yellow-pigmented, hydmogen-oxidizing bacteria. (A) Reduced-minus-oxidized difference spectra of membrane fractions from logarithmicphase, heterotrophically grown cells in $0.05 \mathrm{M} \mathrm{KP}$ buffer, pH 7.0. (a) Heterotrophically grown P. pseudoflava GA3 (spectrum identical to that of strain GA1); (b) autotrophically grown P. pseudoflava GAI; (c) heterotrophically grown $A$. paradoxus $A T C C$ 17713. (B) Reduced-minus-oxidized difference spectra of cytochromes extracted with $50 \%$ pyridine in $0.1 \mathrm{~N}$ $\mathrm{NaOH}$. (a) Logarithmic-phase, heterotrophically grown P. pseudoflava GA3; (b) autotrophically grown $P$. pseudoflava GA3 harvested in the late stationary growth phase; (c) logarithmic-phase, heterotrophically grown A. paradoxus ATCC 17713.
Davis et al. $(4,5)$ identified the pigments of the yellow-pigmented, gram-negative hydrogen bacteria as carotenoids. Mass spectra of some of the pigmented compounds isolated from $P$. pseudoflava failed to reveal evidence of carotenoids. Neither the fragments characteristic of carotenoid molecules nor a clear molecular ion could be detected.

Susceptibility to bacteriophages, bacteriostatic agents, and antibiotics. Phage typing did not reveal a close relationship between strains of $P$. pseudoflava and those of the other gram-negative hydrogen bacteria. Temperate phages for some strains of $P$. pseudoflava had a very restricted host range and were inactive towards strains of $P$. flava, $P$. palleronii, $A$. paradoxus, and 40 strains of $A$. eutrophus.

The growth of $P$. flava and of all strains of $P$. pseudoflava was inhibited by $100 \mu \mathrm{g}$, but not by $50 \mu \mathrm{g}$, of sodium dodecyl sulfate per $\mathrm{ml}$; by $3 \%$, but not $2 \%$, glycine; by $\mathrm{NaCl}(5 \%)$; by Tween 20 (3\%); and by sodium azide $(100 \mu \mathrm{g} / \mathrm{ml})$. In contrast to $P$. flava, the strains of $P$. pseudoflava were not susceptible to methionine ( $2 \%$ ), Tween $80(3 \%)$, or Tween 40 (3\%). Even greater resistance was shown by $A$. paradoxus ATCC 17713: this strain was susceptible only to glycine (3\%), $\mathrm{NaCl}(5 \%)$, and sodium azide $(100 \mu \mathrm{g} / \mathrm{ml})$ whereas $P$. palleronii ATCC 17724 and ATCC 17728 were inhibited by almost all bacteriostatic agents tested.

The results of the antibiotic susceptibility tests are presented in Table 6 . In contrast to the Pseudomonas strains, all strains of $A$. paradoxus proved to be less susceptible and had a very homologous resistance pattern.

Serological relatedness of $P$. pseudoflava to other gram-negative hydrogen bacteria. Antisera prepared from Formalin-killed cells of three $P$. pseudoflava strains agglutinated not only the homologous strains, but also three heterologous strains of this species with the same or slightly minor agglutination titers (Table 7). The agglutination tests with antisera for $P$. pseu-

TARLE 5. Absorption maxima and $R_{f}$ values of pigment components of Pseudomonas pseudoflava

\begin{tabular}{|c|c|c|c|c|}
\hline \multirow{3}{*}{ Compound } & \multirow{3}{*}{ Absorption maxima in acetone } & \multicolumn{3}{|c|}{$R_{f}$ value } \\
\hline & & \multicolumn{2}{|c|}{ Schleicher and Schüll no. 287} & \multirow{2}{*}{$\begin{array}{c}\text { Kieselgel G } \\
(30 \%)^{u}\end{array}$} \\
\hline & & $10 \%^{a}$ & $20 \%^{a}$ & \\
\hline "Neutral" 1 & $(400), 423,446$ & 0.56 & 0.89 & 0.43 \\
\hline "Neutral" 2 & $(400), 423,446$ & 0.33 & 0.78 & 0.35 \\
\hline "Acidic" 1 & $327,(400), 423,446$ & 0.00 & 0.00 & 0.05 \\
\hline $\begin{array}{l}\text { "Acidic"- } \\
\text { peracetate }\end{array}$ & $(400), 423,446$ & $\mathrm{ND}^{h}$ & ND & 0.50 \\
\hline
\end{tabular}

${ }^{a}$ Percent acetone in petroleum ether.

${ }^{b}$ ND. Not determined. 
TABLE 6. Antibiotic susceptibility patterns of strains of Pseudomonas pseudoflava and of other yellowpigmented, hydrogen-oxidizing bacteria ${ }^{\alpha}$

\begin{tabular}{|c|c|c|c|c|c|c|c|c|c|c|c|}
\hline \multirow{2}{*}{ Species } & \multirow{2}{*}{ Strains } & \multicolumn{10}{|c|}{ Level of susceptibility ${ }^{b}$} \\
\hline & & Am & $\mathbf{M e}$ & $\mathrm{Ch}$ & Te & Er & St & $\mathbf{K a}$ & $\mathrm{Ne}$ & Po & No \\
\hline Pseudomonas pseudoflav & $\begin{array}{l}\text { GA1, GA2, GA3, GA4, } \\
\text { GA5, SA27 }\end{array}$ & + & + & + & + & + & + & + & + & + & + \\
\hline Pseudomonas sp. & GA6 & - & - & + & + & + & + & + & + & + & + \\
\hline Pseudomonas flava & DSM 619 & + & + & + & + & + & + & + & + & + & + \\
\hline $\begin{array}{l}\text { Pseudomonas palleronii } \\
\text { P. palleronii } \\
\text { P. palleronii } \ldots \ldots \ldots\end{array}$ & $\begin{array}{l}\text { ATCC } 17724 \\
\text { RH2 } \\
\text { Z17, Z31, Z33 }\end{array}$ & $\begin{array}{l}- \\
+ \\
+\end{array}$ & $\begin{array}{l}- \\
+ \\
+\end{array}$ & $\begin{array}{l}+ \\
+ \\
+\end{array}$ & $\begin{array}{l}+ \\
+ \\
+\end{array}$ & $\begin{array}{l}+ \\
+ \\
+\end{array}$ & $\begin{array}{l}+ \\
+ \\
+\end{array}$ & $\begin{array}{l}- \\
+ \\
-\end{array}$ & $\begin{array}{l}+ \\
+ \\
+\end{array}$ & $\begin{array}{l}+ \\
\pm \\
\pm\end{array}$ & $\begin{array}{l}+ \\
+ \\
+\end{array}$ \\
\hline $\begin{array}{l}\text { Alcaligenes paradoxus } \\
\text { A.paradoxus } \ldots \ldots \ldots \\
\text { A.paradoxus } \ldots \ldots \ldots\end{array}$ & $\begin{array}{l}\text { ATCC } 17712,17713,17715 \\
\text { ATCC } 17722 \\
.12 x\end{array}$ & $\begin{array}{l}- \\
- \\
-\end{array}$ & $\begin{array}{l}- \\
-\end{array}$ & $\begin{array}{l}+ \\
+ \\
\pm\end{array}$ & $\begin{array}{l}+ \\
+ \\
+\end{array}$ & $\begin{array}{l}- \\
\bar{I}\end{array}$ & $\begin{array}{l}- \\
+ \\
-\end{array}$ & $\begin{array}{l}+ \\
+ \\
+\end{array}$ & $\begin{array}{l}+ \\
+ \\
+\end{array}$ & $\begin{array}{l}+ \\
+ \\
+\end{array}$ & $\bar{z}$ \\
\hline
\end{tabular}

abbreviations (quantity of antibiotic is given in parentheses): Am, ampicillin (10 $\mu \mathrm{g})$; ATCC, American Type Culture Collection, Rockville, Md.; Ch, chloramphenciol (30 $\mu \mathrm{g}$ ); DSM, Deutsche Sammlung von Mikroorganismen, Göttingen; Er, erythromycin (15 $\mu \mathrm{g})$; $\mathrm{Ka}$, kanamycin $(30 \mu \mathrm{g})$; Me, methicillin $(5 \mu \mathrm{g})$; Ne, neomycin (30 $\mu \mathrm{g})$; No, novobiocin $(30 \mu \mathrm{g})$; Po, polymyxin B (300 U); St, streptomycin $(10 \mu \mathrm{g})$; Te, tetracycline $(30 \mu \mathrm{g})$.

${ }^{b}$ Susceptibility was recorded from disk zone inhibition measured (in millimeters) from the edge of the susceptibility disks (Oxoid). Inhibition zones smaller than $2 \mathrm{~mm}$ indicated resistance (-); those between 2 and $5 \mathrm{~mm}$ indicated weak susceptibility $( \pm)$; and those above $5 \mathrm{~mm}$ indicated full susceptibility $(+)$.

TABLE 7. Agglutination tests with antisera from rabbits immunized with Formalin-killed cells of Pseudomonas pseudoflava

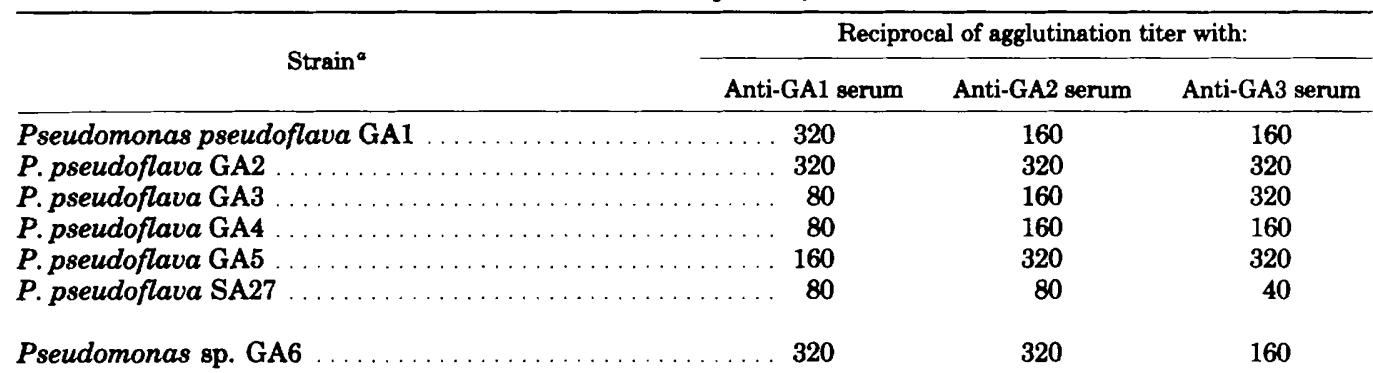

Pseudomonas facilis ATCC 17695 40 40 80

${ }^{a}$ All other strains tested, viz., Pseudomonas flava, $P$. saccharophila ATCC 15946, $P$. palleronii ATCC 17724, ATCC 17728, RH2, Z17, Z31, and Z33, P. delafieldii ATCC 17505, Alcaligenes paradoxus ATCC 17712, ATCC 17713, ATCC 17715, ATCC 17722, and 12x, A. eutrophus ATCC 17697, ATCC 17699, Paracoccus denitrificans ATCC 17741, DSM 413, and DSM 415, either showed no agglutination reaction at all or were agglutinable only to a slight degree without clearing of the supernatant.

doflava were extended to 20 strains of gramnegative hydrogen bacteria, which included eight different species of the genera Pseudomonas, Alcaligenes, and Paracoccus. Cross-agglutination was observed only with Pseudomonas facilis ATCC 17695.

Since some of the examined strains were autagglutinable to a certain degree and the results of serological studies on the genus Pseudomonas were considered to give meaningless results when living cells were used for agglutination tests (12), the agglutination tests with strain GA3 antiserum were repeated with autoclaved $\left(115^{\circ} \mathrm{C}, 1 \mathrm{~h}\right)$ and washed cells. However, no further cross-reactions were observed. The agglutination titers differed only slightly from those obtained with the use of living cells.

Preliminary immunodiffusion tests were done with selected strains only, because the results were inconsistent. Positive serological reactions were observed with homologous and heterologous strains of $P$. pseudoflava and the three antisera. Furthermore, the GA1 antiserum, which produced the most easily visible precipitation lines, gave slight serological cross-reactions with two strains of $A$. paradoxus (ATCC 17713 and ATCC 17722) and one strong precipitation line with $P$. flava.

DNA base composition and DNA-DNA homology. The DNA base compositions of the strains of $P$. pseudoflava (GA1, GA2, GA3, GA4, GA5, and SA27) ranged from 66.5 to $68.0 \mathrm{~mol} \%$ 
$\mathrm{G}+\mathrm{C}$ as estimated by the thermal-denaturation and the buoyant-density methods. The degree of binding of the DNAs from strains GA1, GA2, GA4, GA5, and SA27 to the DNA from strain GA3 ranged from 85 to $100 \%$ as calculated from the optical-renaturation rates (6). Only GA6 DNA gave a percentage as low as $61 \%$. The degree of binding of the DNAs from the $P$. pseudoflava strains to the DNA from $P$. flava was lower and ranged from 52\% (GA2 DNA) up to $68 \%$ (GA5 DNA). These results, diagrammatically represented in Fig. 5, indicate a high homology within the $P$. pseudoflava strains and a moderate homology with $P$. flava.

\section{DISCUSSION}

All of the newly isolated hydrogen-oxidizing bacteria fitted well, morphologically, into the genus Pseudomonas, as was revealed by electron microscope observation of flagellation and of thin sections of cells. The demonstration of a glycogen-like polysaccharide as a reserve material in addition to $\mathrm{PBH}$ was an unusual feature of the new strains. Among the hydrogen bacteria, the new strains exhibited a high degree of morphological and ultrastructural similarity only to Pseudomonas flava, as was shown in a morphological survey of the gram-negative hydrogen bacteria (36).

The strains of $P$. pseudoflava were shown to possess a rather versatile metabolism. Their ability to grow on a wide range of mono- and disaccharides is a remarkable property. With respect to this ability, these strains are related to $P$. flava and $P$. saccharophila and are clearly distinct from the other yellow-pigmented hydro-

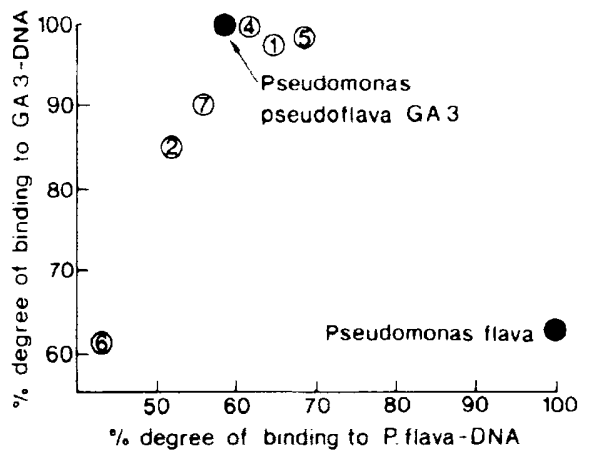

FIG. 5. Intra-and interspecies DNA-DNA homology of P. pseudoflava and P. flava. The DNA homology relationship was calculated by the method of DeLey et al. (6) as the percent degree of binding to two reference DNAs (dark circles). The strains are arranged in the diagram according to the degree of binding of their DNAs to $P$. pseudoflava GA3 DNA and also to $P$. flava DNA. The numbers in the circles represent the DNAs of the following strains: 1, GA1; 2, GA2; 4, GA4; 5, GA5; 6, GA6; and 7, SA27. gen bacteria, such as Alcaligenes paradoxus and especially $P$. palleronii and "Corynebacterium" autotrophicum. $P$. palleronii could not grow at all on sugars; "Corynebacterium" autotrophicum used only fructose and sucrose; and $A$. paradoxus used only monosaccharides. The aerobic production of acid from carbohydrates appears to be a very useful test for the differentiation of yellow-pigmented hydrogen bacteria.

The difference between the nutritional patterns of $P$. pseudoflava and $P$. flava lies in the restricted number of substrates supporting growth of the latter. In this and in some other respects (pigmentation and tolerance to $20 \%$ oxygen), the strains of $P$. pseudoflava resemble Pseudomonas sp. strain 450 isolated by Davis et al. and tentatively assigned to Pseudomonas flava (5). This strain has apparently been lost. $P$. flava, which lost its chemolithoautotrophic ability soon after its isolation (15), grows slowly and unreliably. Therefore, failure to grow on a certain substrate may be due to delayed induction. The $P$. pseudoflava strains are rather active denitrifiers. However, they differ in many respects from the well-characterized denitrifying species of the genus Pseudomonas ( $P$. aeruginosa, $P$. fluorescens, $P$. stutzeri, $P$. mendocina, P. pseudomallei, $P$. caryophylli, P. picketti, and $P$. solanacearum) and cannot be assigned to any of them.

The analysis of the cytochrome patterns of the $P$. pseudoflava strains, with particular attention to cytochrome $d$, was performed for taxonomic reasons because the possession of cytochrome $d\left(a_{2}\right)$ had been introduced by Davis et al. (4) as a criterion for distinguishing between $A$. paradoxus and other yellow gram-negative hydrogen bacteria. However, the authors (4) did not report the exact culture conditions for the demonstration of cytochrome $d$. The cytochrome pattern is not a very helpful criterion for the classification and identification of gram-negative hydrogen bacteria if the exact cultural conditions, including time of harvest, are not provided.

The demonstration of small amounts of cytochrome $d\left(a_{2}\right)$ in P. pseudoflava GA3 was possible only in pyridine- $\mathrm{NaOH}$ extracts of autotrophically grown cells harvested in the late stationary growth phase $(36 \mathrm{~h})$. The presence of cytochrome $d$ in aerobic bacteria, exclusively in the stationary phase of growth, as with $A$. eutrophus H16 (26), is not an unusual feature. Furthermore, $P$. pseudoflava GA3 contained greater amounts of heme $d$ and heme $c$ in the soluble cytoplasmic fraction after anaerobic growth on nitrate (I. Probst, personal communication); under these same conditions, Paracoccus denitrificans produced cytochrome $c-d$, which is associ- 
ated with nitrite reductase activity $(22,27)$. These results indicate that the possession of cytochrome $d$ is not restricted to any one species among the hydrogen bacteria and thus is not a taxonomically useful criterion.

The pigments of $P$. pseudoflava appear to be similar to those of $P$. palleronii and $A$. paradoxus and different from those of P. flava and "Corynebacterium" autotrophicum. Most of these pigments have been taken for carotenoids, but only in "Corynebacterium" autotrophicum $14 \mathrm{~g}$ has the carotenoid nature of the pigments been demonstrated (23). The pigments of Xanthomonas, which at first had been described as carotenoids, turned out to belong to quite a different group of compounds (1). The pigments of $P$. pseudoflava have not been identified as of the present.

Typing with phages for $P$. pseudoflava was not very useful because the phages proved to be restricted to their original hosts, probably due to their temperate nature. Tests for susceptibility to antibiotics proved to be of value for differentiation between $A$. paradoxus and strains of the genus Pseudomonas.

The serological relatedness of the $P$. pseudoflava strains was indicated by cross-agglutination of whole cells and cross-reaction of bacterial homogenates in immunodiffusion tests with antisera from some strains of $P$. pseudoflava. It was impossible at this stage of investigation to decide whether the new species was internally serologically homologous or not. There must be at least one common $\mathbf{O}$ antigen for the six strains of $\boldsymbol{P}$. pseudoflava. Cross-agglutination has only been detected with the type strain of $P$. facilis, whereas immunodiffusion tests disclosed further serological relations to $P$. flava and two strains of $A$. paradoxus. Immunological cross-reactions between Pseudomonas and Alcaligenes have also been found by Detrick-Hooks and Kennedy (7) in immunodiffusion tests with bacterial homogenates.

It should be pointed out that the results of clustering strains on the basis of common $\mathrm{O}$ antigens may differ from the taxonomic arrangement of the strains because antigens transcend generic boundaries. In this context we refer to the serological relationships that exist between many different gram-negative hydrogen bacteria (7). Furthermore, immunological cross-reactions for hydrogenase, a prominent enzyme of the hydrogen bacteria, were detected with many strains of different species and even of different genera by Schink (Ph.D. thesis, University of Göttingen, 1977). For example, the antiserum towards the membrane-bound, solubilized, purified hydrogenase of Alcaligenes eutrophus H16 gave a cross-reaction with the membrane-bound hydrogenase of $P$. pseudoflava GA3.

The DNA base compositions of the new strains were in the range of those reported for the genus Pseudomonas and for most species of the gram-negative hydrogen bacteria (5). However, G+C data provide little help for generic differentiation within this group of bacteria. In this respect, nucleic acid homology data were more conclusive (25). By calculating the degree of binding of the DNAs of $P$. pseudoflava GA1, GA2, GA3, GA4, GA5, and SA27, a high interstrain DNA homology was found; this finding gave support to the recognition of these strains as constituting a unique bacterial species, which we have named $P$. pseudoflava. A composite description of this species, based on six strains, is given below.

\section{Pseudomonas pseudoflava sp. nov.}

During exponential growth, the cells are ovoid with a length of $1.0 \mu \mathrm{m}$; old cells are rod-shaped with a length of up to $2.5 \mu \mathrm{m}$. Cells in the exponential phase of growth occur singly or in pairs and are motile by one, rarely two, polarly or subpolarly inserted flagella with an average diameter of $15 \mathrm{~nm}$. Transitional flocculent growth with ring formation occurs in liquid complex media or in sugar-mineral media. Gramnegative. PHB, glycogen, and polyphosphate are accumulated intracellularly as reserve materials.

Colonies are yellow from the production of an intracellular pigment of unknown structure with absorption maxima at (400), 423, and 446 $\mathrm{nm}$ in acetone. Slime formation by this organism has never been observed.

Chemoorganotrophic and facultatively chemolithotrophic, obtaining energy from the oxidation of molecular hydrogen possesses a very active particulate hydrogenase, which does not reduce nicotinamide adenine dinucleotide. With organic substrates, nitrate is rapidly and abundantly reduced to $\mathrm{N}_{2}$. Hydrolyzes Tween 80 but not exogenous PHB, gelatin, casein, urea, esculin, or starch.

Organic growth factors are not required. Grows autotrophically in atmospheres containing hydrogen, oxygen, and carbon dioxide, with a generation time of between 2 and $3 \mathrm{~h}$; tolerant to 20 or $25 \%$ oxygen. At least 42 different organic compounds can serve as sole carbon sources for heterotrophic growth. Among the carbon sources used by all of the strains are many mono- and disaccharides, polyols, amino acids, and aromatic compounds.

Obligately aerobic except for nitrate respiration. Acids are produced aerobically from many carbohydrates. Catalase is weakly produced. Ox- 
TABle 8. Differentiation of Pseudomonas pseudoflava from Pseudomonas flava

\begin{tabular}{|c|c|c|}
\hline Distinguishing character & P. pseudoflava & P. flava \\
\hline \multicolumn{3}{|l|}{ Growth on: } \\
\hline Xylose $\ldots \ldots \ldots \ldots \ldots \ldots$ & + & - \\
\hline$p$-Hydroxybenzoate & + & - \\
\hline Phenol . . . . . . & + & - \\
\hline L-Lysine $\ldots \ldots$ & + & - \\
\hline L-Leucine $\ldots \ldots \ldots \ldots \ldots$ & + & - \\
\hline L-Isoleucine $\ldots \ldots \ldots \ldots$ & + & - \\
\hline L-Tryptophan $\ldots \ldots \ldots \ldots$ & + & - \\
\hline L-Asparagine $\ldots \ldots \ldots \ldots \ldots$ & + & - \\
\hline L-Phenylalanine & + & - \\
\hline L-Tyrosine $\ldots \ldots \ldots \ldots \ldots \ldots$ & + & - \\
\hline \multicolumn{3}{|l|}{ Cross-agglutination with: } \\
\hline GAl antiserum $\ldots \ldots \ldots \ldots \ldots$ & + & - \\
\hline GA2 antiserum $\ldots \ldots \ldots \ldots$ & + & - \\
\hline GA3 antiserum $\ldots \ldots \ldots \ldots$ & + & - \\
\hline Denitrification & + & - \\
\hline Tolerance to $20 \% \mathrm{O}_{2}$ & + & - \\
\hline Temperature optimum & $35-38^{\circ} \mathrm{C}$ & $30^{\circ} \mathrm{C}$ \\
\hline $\begin{array}{l}\text { Absorption maxima of pigments (in } \\
\text { acetone) }\end{array}$ & $\begin{array}{lr}\text { "Neutral" } & (400) 423446 \\
\text { "Acidic" } & 327(400) 423446\end{array}$ & $\begin{array}{ll}\text { "Neutral" } & (415) 442(468)^{a} \\
\text { "Acidic" } & (415) 440(465)^{a}\end{array}$ \\
\hline DNA-DNA homology $\ldots \ldots \ldots \ldots$ & $\begin{array}{l}\text { High-interstrain DNA-DNA ho- } \\
\text { mology }(85-100 \%)\end{array}$ & $\begin{array}{l}\text { Only moderate DNA-DNA ho- } \\
\text { mology to the strains of } P \text {. pseu- } \\
\text { doflava (52-68\%) }\end{array}$ \\
\hline
\end{tabular}

${ }^{a}$ Data from D. Davis (Ph.D. thesis).

idase positive; possesses cytochromes of the $a, b$, and $c$ types.

The temperature for optimal growth is between 35 and $38^{\circ} \mathrm{C}$. The maximum temperature for growth is between 40 and $41^{\circ} \mathrm{C}$.

Some strains are susceptible to temperate phages, the host range of which is very restrictive. $\mathrm{G}+\mathrm{C}$ content of DNA: 66.5 to $68.0 \mathrm{~mol} \%$. There is high interstrain DNA homology.

Type strain: GA3 (= DSM 1034).

Source: Isolated from soil, mud, or water by liquid enrichment for hydrogen bacteria and by the use of a gas atmosphere consisting of $10 \%$ $\mathrm{O}_{2}, 10 \% \mathrm{CO}_{2}$, and $80 \% \mathrm{H}_{2}$.

The strains of $P$. pseudoflava differ from $P$. flava with respect to the characters listed in Table 8.

\section{ACKNOWLEDGMIENTS}

We are grateful to I. Probst, who made the cytochrome difference spectra, to $K$. Schmidt for assistance in the analysis of the pigments, to G. Remberg for performing mass spectroscopy, and to $J$. Wiegel for performing the polymyxin $B$ treatment. We thank $H$. J. Knackmuss for providing us with pure glycogen and R. Ansorg for introducing us to serology and for valuable discussions. We received generous help from $R$. Brinkmann. We are indebted to M. P. Starr for reading the manuscript.

\section{REPRINT REQUESTS}

Address reprint requests to: Prof. Dr. H. G. Schlegel, lnstitut für Mikrobiologie, Abteilung für Bakterienphysiologie der Universität Göttingen, Grisebachstr. 8, 3400 Göttingen, Federal Republic of Germany.

\section{LTERATURE CITED}

1. Andrewes, A. G., S. Herzberg, S. Liaaen-Jensen, and M. P. Starr. 1973. Xanthomonas pigments. 2. The Xanthomonas "carotenoids"-non-carotenoid, brominated aryl-polyene esters. Acta Chem. Scand. 27:2383-2395.

1a.Auling, G., F. Mayer, and H. G. Schlegel. 1977. Isolation and partial characterization of normal and defective bacteriophages for Pseudomonas pseudoflava. Arch. Microbiol. 115:237-248.

2. Bergmeyer, H. U. 1974. Methoden der enzymatischen Analyse. Verlag Chemie, Weinheim.

3. Cowan, S. T. 1974. Cowan and Steel's manual for the identification of medical bacteria, 2nd ed. Cambridge University Press, New York.

4. Davis, D. H., M. Doudoroff, R. Y. Stanier, and M. Mandel. 1969. Proposal to reject the genus Hydrogenomonas: taxonomic implications. Int. J. Syst. Bacteriol. 19:375-390.

5. Davis, D. H., R. Y. Stanier, M. Doudoroff, and M. Mandel. 1970. Taxonomic studies on some Gram-negative polarly flagellated "hydrogen bacteria" and related species. Arch. Mikrobiol. 70:1-13.

6. DeLey, J., H. Cattoir, and A. Reynaerts. 1970. The quantitative measurement of DNA-hybridization from renaturation rates. Eur. J. Biochem. 12:133-142. 
7. Detrick-Hooks, B., and E. R. Kennedy. 1974. Immunological cross-reactions among strains of Hydrogenomonas, Pseudomonas and Alcaligenes. Antonie van Leeuwenhoek J. Microbiol. Serol. 40:577-584.

8. Doudoroff, M. 1940. The oxidative assimilation of sugars and related substrates by Pseudomonas saccharophila with a contribution to the problem of the direct respiration of di- and polysaccharides. Enzymologia 9:52-72.

9. Falk, J. E. 1964. Porphyrins and metalloporphyrins. BBA Library, vol. 2. Elsevier, Amsterdam.

10. Ghosh, H. P., and J. Preiss. 1965. The isolation and characterization of glycogen from Arthrobacter sp. NRRLB 1973. Biochim. Biophys. Acta 104:274-277.

11. Gordon, R. E., W. C. Haynes, and C. Hor-Nay Pang. 1973. The genus Bacillus. Agriculture handbook no. 247. U.S. Department of Agriculture, Washington, D.C.

12. Habs, I. 1975. Untersuchungen über die O-Antigene von Pseudomonas aeruginosa. Z. Hyg. Infektionskr. 144:218-228.

13. Jensen, A., and S. Liaken-Jensen. 1959. Quantitative paper chromatography of carotenoids. Acta Chem. Scand. 13:1863-1868.

14. Jüttner, R. R., L. M. Lafferty, and H. J. Knackmuss. 1975. A simple method for the determination of poly$\beta$-hydroxybutyric acid in microbial biomass. Eur. J. Appl. Microbiol. 1:233-237.

15. Kluyver, A. J., and A. Manten. 1942. Some observations on the metabolism of bacteria oxidizing molecular hydrogen. Antonie van Leeuwenhoek J. Microbiol. Serol. 8:71-85.

16. Kraft, M. 1976. Struktur- und Absorptions- spektroskopie organischer Naturstoffe, p. 140. Steinkopff, Darmstadt.

17. Kucsera, G. 1973. Proposal for standardization of the designations used for serotypes of Erysipelothrix rhusiophathiae (Migula) Buchanan. Int. J. Syst. Bacteriol. 23: $184-188$.

18. Liaaen-Jensen, S. 1971. Isolation, reactions, p. 61-188. In Otto Isler (ed.), Carotenoids. Verlag Birkhäuser, Basel.

19. Lounatmaa, K., P. H. Mäkelä, and M. Sarvas. 1976. Effect of polymyxin on the ultrastructure of the outer membrane of wild-type and polymyzin-resistant strains of Salmonella. J. Bacteriol. 127:1400-1407.

20. Mandel, M., C. L. Schildkraut, and J. Marmur. 1968. Use of $\mathrm{CsCl}$ density gradient analysis for determining the guanine plus cytosine content of DNA. Methods Enzymol. 12B:184-195.

21. Marmur, J., and P. Doty. 1962. Determination of the base composition of deoxyribonucleic acid from its thermal denaturation temperature. J. Mol. Biol. 5:109-118.

22. Newton, N. 1967. A soluble cytochrome containing c-type and $a_{2}$-type haem groups from Micrococcus denitrificans. Biochem. J. 105:21c.

23. Nybraaten, G., and S. Liaaen-Jensen. 1974. Bacterial carotenoids. XIIII. Zeaxanthin mono- and dirhamnoside. Acta Chem. Scand. Ser. B 28:1219-1224.
24. Ohara, S., T. Sato, and M. Homma. 1974. Serological studies on Francisella tularensis, Francisella novicida, Yersinia philomiragia, and Brucella abortus. Int. J. Syst. Bacteriol. 24:191-196.

25. Palleroni, N. J., R. W. Ballard, E. Ralston, and $M$. Doudoroff. 1972. Deoxyribonucleic acid homologies among some Pseudomonas species. J. Bacteriol. 110:1-11.

26. Probst, I., and H. G. Schlegel. 1976. Respiratory components and oxidase activities in Alcaligenes eutrophus. Biochim. Biophys. Acta 440:412-428.

27. Sapshead, L. M., and J. W. T. Wimpenny. 1972. The influence of oxygen and nitrate on the formation of the cytochrome pigments of the aerobic and anaerobic respiratory chain of Micrococcus denitrificans. Biochim. Biophys. Acta 267:388-397.

28. Savel'eva, N. D., and T. N. Zhilina. 1968. Taxonomy of hydrogen bacteria. Mikrobiologiya 37:68-73.

29. Schatz, A., and C. R. Bovell. 1952. Growth and hydrogenase activity of a new bacterium, Hydrogenomonas facilis. J. Bacteriol. 63:87-98.

30. Schlegel, H. G. 1976. The physiology of hydrogen bacteria. Antonie van Leeuwenhoek J. Microbiol. Serol. 42:181-201.

31. Schlegel, H. G., H. Kaltwasser, and G. Gottschalk. 1961. Ein Submersverfahren zur Kultur wasserstoffoxidierenden Bakterien: wachstumsphysiologische Untersuchungen. Arch. Mikrobiol. 38:209-222.

32. Schubert, R. H. W. 1960 . Untersuchungen über die Merkmale der Gattung Aeromonas. Zentralbl. Bakteriol. Parasitenkd. Infektionskr. Hyg. Abt. 1 Orig. 180:310-327.

33. Sigal, N., J. Cattaneo, and I. H. Segel. 1964. Glycogen accumulation by wild-type and uridine diphosphate glucose pyrophosphorylase-negative strains of Escherichia coli. Arch. Biochem. Biophys. 108:440-451.

34. Stahl, E. 1967. Dünnschicht Chromatographie. 2. Aufl. Springer-Verlag, Heidelberg.

35. Stanier, R. Y., N. J. Palleroni, and M. Doudoroff. 1966. The aerobic peeudomonads: a taxonomic study. J. Gen. Microbiol. 43:159-271.

36. Walther-Mauruschat, A., M. Aragno, F. Mayer, and H. G. Schlegel. 1977. Micromorphology of Gram-negative hydrogen bacteria. II. Cell envelope, membranes and cytoplasmic inclusions. Arch. Microbiol. 114: 101-110.

37. Weston, J. A., and C. J. Knowles. 1973. A soluble CO-binding $c$-type cytochrome from the marine bacterium Beneckea natriegens. Biochim. Biophys. Acta 305:11-18.

38. Zevenhuizen, L. P. T. M., and A. G. Ebbink. 1974 Interrelations between glycogen, poly- $\beta$-hydroxybutyric acid and lipids during accumulation and subsequent utilization in a Pseudomonas. Antonie van Leeuwenhoek J. Microbiol. Serol. 40:103-120. 